\title{
Thinning 'Golden Delicious' and Spur 'Delicious' with Combinations of Carbamates and NAA
}

\author{
Richard P. Marini \\ Department of Horticulture, Virginia Polytechnic Institute and State \\ University, Blacksburg, VA 24061-3083
}

Additional index words. Malus $\times$ domestica, oxamyl, carbaryl, fruit set, fruit size

\begin{abstract}
For 2 years, 'Redchief Delicious' apple (Malus $\times$ domestica Borkh.) trees were treated with combinations of NAA and oxamyl and 'Smoothee Golden Delicious' trees were treated with combinations of NAA and carbaryl. Oxamyl, at concentrations of 250 to $750 \mathrm{mg} \cdot \mathrm{L}^{-1}$, but not NAA at concentrations of 1 to $6 \mathrm{mg} \cdot \mathrm{L}^{-1}$, reduced fruit set, yield and crop value. NAA did not consistently affect average fruit weight or the percentage of small fruits on 'Redchief Delicious' trees. Carbaryl reduced fruit set and yield on 'Smoothee Golden Delicious' trees one of the two years. Fruit set and yield were negatively related to NAA concentration both years. In one of the two years the combination of NAA plus carbaryl was more effective than NAA alone. Treatments that provided adequate thinning tended to reduce crop value because the increase in fruit size did not compensate for the reduced yields. Chemical names used: 1 -naphthyl- $N$-methylcarbamate (carbaryl); methyl $N^{\prime}, N^{\prime}$-demethyl- $N$ [(methylcarbomoyl)oxy]-1thiooxamimidate (oxamyl); 1-naphthaleneacetic acid (NAA).
\end{abstract}

Spur 'Delicious' and 'Golden Delicious' are the two most widely planted apple cultivars in Virginia. Both cultivars are difficult to adequately thin. Spur 'Delicious' trees are usually thinned with one of the carbamates, carbaryl or oxamyl, often with unsatisfactory results. The thinning response to oxamyl (Marini, 1997), but not carbaryl (Batjer and Thompson, 1961) is dose dependent, so additional thinning activity may be obtained by increasing the concentration of oxamyl. To obtain more thinning, superior oil, Accel $^{\circledR}$, or NAA are sometimes added to the carbamates (Byers, 1978; Marini, 1997; Rogers and Williams, 1977). 'Golden Delicious' is usually thinned with NAA at rates of 6 to $12 \mathrm{mg} \cdot \mathrm{L}^{-1}$ plus a surfactant. Because NAA often inadequately thins 'Golden Delicious' trees, some commercial producers combine carbaryl and NAA to increase the thinning response.

Although research data are inconsistent (Marini, 1996, 1997), many producers feel that combinations of carbamates and NAA provide superior thinning compared to either alone. Few experiments have been designed to determine the dose response of NAA when combined with carbamates. Data from some thinning experiments also indicate that NAA may reduce the crop load without improving fruit size (Rogers and Williams, 1977; Byers et al., 1982). Average fruit size was usually estimated by subsampling trees. Estimates of average fruit weight obtained from subsamples may differ from the true value by as much as $15 \%$ and may lead to erroneous conclusions concerning the effect of treatments on average fruit size (Marini, 2001). Therefore, there is a need for similar data obtained by harvesting the entire crop.

Received for publication 3 Apr. 2001. Accepted for publication 14 Aug. 2001
The experiments in this study were designed to evaluate NAA, over a range of concentrations when applied alone and when combined with a carbamate, for thinning spur 'Delicious' and 'Golden Delicious' trees. The effects of treatments on average fruit size and crop value were also studied.

\section{Materials and Methods}

General. The trees used for these experiments were 'Campbell Redchief Delicious'/ M.26 planted $3.0 \times 6.4 \mathrm{~m}$ in 1988 , 'Mercier Redchief Delicious'/M.26 planted 3.0 ×6.4 m in 1989, or 'Smoothee Golden Delicious'/ M.26 planted $3.5 \times 6.4 \mathrm{~m}$ in 1988 . All trees were growing at the Virginia Tech College of Agriculture and Life Sciences Kentland Farm, near Blacksburg, Va. All orchard practices were according to local recommendations. Treatments were applied with a hand-held sprayer to runoff with $\approx 4 \mathrm{~L}$ of solution per tree $(\approx 2,000 \mathrm{~L} / \mathrm{ha})$. Tree height and spread were $\approx 3.4 \mathrm{~m}$ and $3.9 \mathrm{~m}$, respectively. Treatments were applied when average fruit diameter was $\approx 8 \mathrm{~mm}$ for 'Delicious' and $12.0 \mathrm{~mm}$ for 'Smoothee'.

During bloom, the number of flower clusters on each of three limbs per tree was recorded. The number of flower clusters per limb ranged from 70 to 115 . Six weeks after treatment the number of fruit remaining on each limb was recorded and data were expressed as the number of fruit retained per 100 flower clusters. In mid-Sept. all fruit on each tree were harvested, weighed, counted, and segregated into seven categories with a weight sizer. Crop value was estimated for each tree by assuming the following price for U.S. extra fancy-U.S. fancy fruit grades: 60 to $68 \mathrm{~mm}$ $\left(2.5^{\prime \prime} \mathrm{min}\right.$. bags $)=\$ 0.55 / \mathrm{kg}, 69$ to $73.5 \mathrm{~mm}$ $(113$ count $)=\$ 0.58 / \mathrm{kg}$, and $>73.5 \mathrm{~mm}(100$ count and larger $)=\$ 0.63 / \mathrm{kg}$, and juice apples $(<60 \mathrm{~mm})=\$ 0.088 / \mathrm{kg}$. Fruit color and finish did not appear to be influenced by treatment and were not considered while calculating crop values.

'Mercier Redchief Delicious' 1997. During bloom, 48 trees were selected for uniformity of bloom. Three trees were assigned to each of 16 treatments in a completely randomized design (CRD). The experiment was a $4 \times 4$ factorial, with four levels of NAA (K-Salt ${ }^{\mathrm{TM}}$ Fruit Fix 200; AMVAC Chem. Corp., Los Angeles) (0, 2, 4, and $\left.6 \mathrm{mg} \cdot \mathrm{L}^{-1}\right)$ and four levels of oxamyl (Vydate ${ }^{\circledR}$ L; Dupont, Wilmington, Del.) (0, 250, 500, and $\left.750 \mathrm{mg} \cdot \mathrm{L}^{-1}\right)$. All treatments contained Tween 20 (polyoxyethylene sorbitan monolaurate) at the rate of $1.25 \mathrm{~mL} \cdot \mathrm{L}^{-1}$. After grading the fruit, 20 fruit per tree, from the 77 to $83 \mathrm{~mm}$ size category, were selected to evaluate fruit finish. Each fruit was rated on a scale from 1 to 5 : where $1=$ smooth to touch, 2 = enlarged lenticels rough to touch, 3 $=$ russetting between lenticels covering $<10 \%$ of the fruit surface, $4=$ russetting covering $10 \%$ to $25 \%$ of the fruit surface, and $5=$ russetting covering $>25 \%$ of the fruit surface. Fruit rated 1 and 2 were considered U.S. Fancy grade, but fruit rated 3 or greater were considered juice grade.

'Campbell Redchief Delicious' 1998. During bloom, 36 trees were selected for uniformity of bloom. Three trees were assigned to each of 12 treatments in a CRD. The experiment was a $2 \times 6$ factorial, with six levels of NAA $\left(0,1,2,3,4\right.$, and $\left.5 \mathrm{mg} \cdot \mathrm{L}^{-1}\right)$ and two levels of oxamyl $\left(0\right.$, or $\left.600 \mathrm{mg} \cdot \mathrm{L}^{-1}\right)$. All treatments contained Tween 20 at the rate of $1.25 \mathrm{~mL} \cdot \mathrm{L}^{-1}$. Data, other than for russetting, were collected as in the previous experiment.

'Smoothee Golden Delicious', 1997. During bloom, 32 trees were selected for uniformity of bloom. Four trees were assigned to each of eight treatments in a CRD. The experiment was a $2 \times 4$ factorial, with four levels of NAA $(0$, 4,8 , and $12 \mathrm{mg} \cdot \mathrm{L}^{-1}$ ) and two levels of carbaryl (Sevin ${ }^{\circledR}$ XLR Plus; Aventis Crop Science, Research Triangle Park, NC) $\left(0\right.$, or $\left.600 \mathrm{mg} \cdot \mathrm{L}^{-1}\right)$. All treatments contained Tween 20 at the rate of $1.25 \mathrm{~mL} \cdot \mathrm{L}^{-1}$. Data, other than for russetting, were collected as in the previous experiments.

'Smoothee Golden Delicious', 1999. During bloom, 40 trees were selected for uniformity of bloom. Four trees were assigned to each of 10 treatments in a CRD. The experiment was a $2 \times 5$ factorial, with five levels of NAA $\left(0,3.5,7,10.5\right.$, and $\left.14 \mathrm{mg} \cdot \mathrm{L}^{-1}\right)$ and two levels of carbaryl $\left(0\right.$ or $\left.600 \mathrm{mg} \cdot \mathrm{L}^{-1}\right)$. All treatments contained Tween 20 at the rate of 1.25 $\mathrm{mL} \cdot \mathrm{L}^{-1}$. Data, other than for russetting, were collected as for the previous experiments.

Data from each experiment were analyzed as a two-way analysis of variance (ANOVA), with SAS's general linear model (GLM) procedure (Littell, et al., 1991), to test main effects and the interaction. A set of orthogonal contrasts was then constructed to partition the degrees of freedom and sums of squares into components due to linear and quadratic regression; the main effects and all possible interactions were evaluated. 


\section{Results}

'Delicious' fruit set and yield. In 1997, fruit set and fruit harvested per tree declined nonlinearly with increasing concentrations of oxamyl (Fig. 1). Fruit harvested per tree and yield related quadratically to NAA concentration. For fruit set, the oxamyl ${ }_{\text {quadratic }} \times$ $\mathrm{NAA}_{\text {quadratic }}$ interaction term was significant. Fruit set was high for all treatments that did not contain oxamyl, and minimum fruit set and fruit harvested per tree occurred when oxamyl was applied at concentrations of 250 to 750 $\mathrm{mg} \cdot \mathrm{L}^{-1}$

Averaged over all NAA treatments, yield declined linearly with increasing oxamyl concentration (Fig. 1). For most levels of oxamyl, the lowest yields occurred when NAA was applied at 2 and $4 \mathrm{mg} \cdot \mathrm{L}^{-1}$.

In 1998, oxamyl reduced fruit set, the number of fruit harvested per tree, and yield (Fig. 1), but none of these response variables varied systematically as NAA concentration was increased from 0 to $5 \mathrm{mg} \cdot \mathrm{L}^{-1}$.

'Delicious' fruit size and crop value. In 1997, average fruit weight was not influenced by the main effect of NAA, but increased linearly with increasing oxamyl concentration (Fig. 2). At most concentrations of NAA, fruit weight increased with increasing concentrations of oxamyl. For treatments containing oxamyl, the percentage of small fruit $(<64$ $\mathrm{mm}$ ) was $<15 \%$ regardless of NAA concentration. In the absence of oxamyl, the percentage of small fruit was $14 \%$ to $57 \%$ and was minimized when NAA was applied at $2 \mathrm{mg} \cdot \mathrm{L}^{-1}$. NAA did not influence fruit russetting and when oxamyl was not applied the percentage of russetted fruit was $<18 \%$ (data not shown). When oxamyl was applied, $30 \%$ to $55 \%$ of the fruit had some russet, but russetting severity was not concentration-dependent (data not shown). In 1998, average fruit weight was increased by oxamyl, but fruit weight was not related to NAA concentration (Fig. 2). In 1998, the percentage of small fruit was not influenced by any of the treatments, probably because there were few small fruit.

In 1997, the crop value was affected by the main effect of oxamyl, but not NAA. Averaged over all NAA treatments, crop value declined linearly as oxamyl concentration increased (Fig. 2). In 1998 oxamyl, but not NAA reduced crop value.

'Smoothee' fruit set and yield. In 1997, fruit set, number of fruit harvested per tree, and yield per tree were influenced by the main effects of carbaryl and NAA and by their interaction (Fig. 3). Fruit set declined quadratically as NAA concentration was increased, and $8 \mathrm{mg} \cdot \mathrm{L}^{-1}$ caused the lowest fruit set. Carbaryl had little effect on fruit set when combined with NAA at 0 or $4 \mathrm{mg} \cdot \mathrm{L}^{-1}$. When carbaryl was combined with higher concentrations of NAA, fruit set was greater than when NAA was used alone. When applied alone, carbaryl reduced the number of fruit harvested per tree by $\approx 30 \%$. Number of fruit harvested per tree declined with increasing NAA concentration, but the rate of decline was greatest when carbaryl was combined with NAA. When applied alone, carbaryl reduced yield by $<10 \%$. Yield declined nonlinearly as NAA concentration was increased, but when carbaryl was combined with NAA yield was further reduced. In 1999, fruit set was reduced by nearly $50 \%$ by carbaryl and fruit set declined nonlinearly with increasing NAA concentration (Fig. 3). Compared to the nontreated control, application of carbaryl plus NAA at 7 to $14 \mathrm{mg} \cdot \mathrm{L}^{-1}$ reduced fruit set by $\approx 60 \%$. The main effects of carbaryl and NAA, but not their interaction, influenced the number of fruit harvested per tree and yield per tree. Compared to the nontreated control, the number of fruit harvested per tree was reduced by $25 \%$ to $60 \%$ by all treatment combinations except the highest concentration of NAA. When averaged over carbaryl treatments, number of fruit harvested per tree and yield per tree declined linearly with increasing NAA concentrations

'Smoothee' fruit size and crop value. In 1997, average fruit weight was increased by the main effect of carbaryl and fruit weight was nonlinearly and positively related to the main effect of NAA (Fig. 4). The interaction of carbaryl $\times \mathrm{NAA}_{\text {linear }}$ was significant because NAA did not increase fruit weight unless combined with carbaryl. The percentage of small fruit was reduced by the main effect of carbaryl, and was linearly and negatively related to the main effect of NAA. The smallest per-

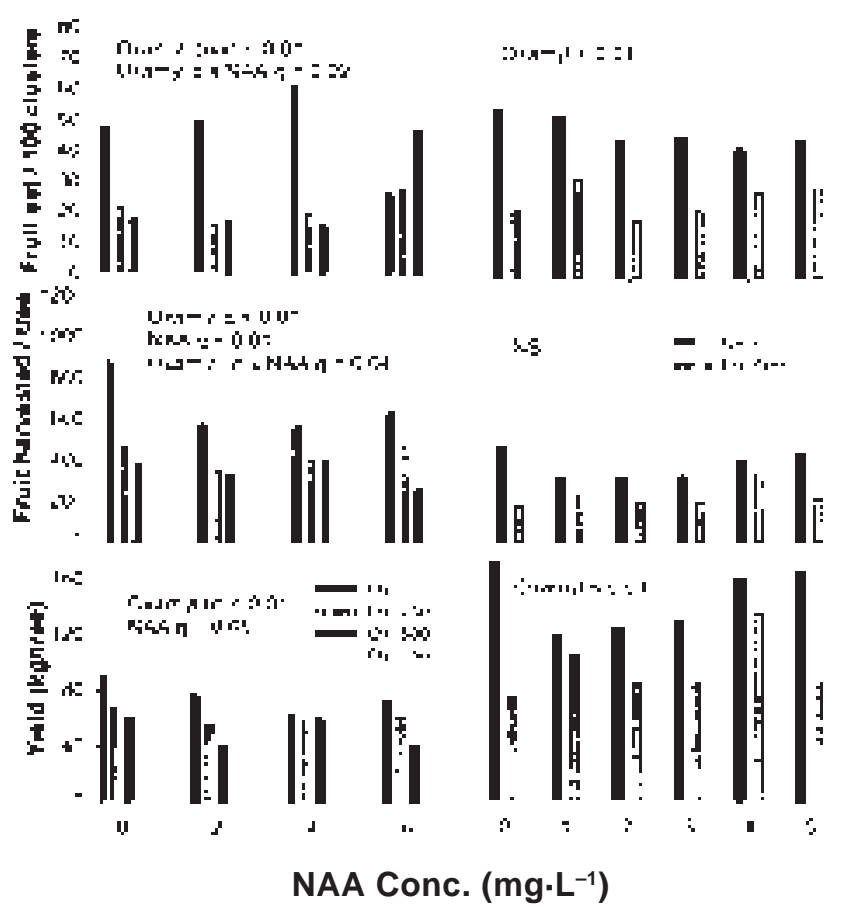

Fig. 1. Fruit set per 100 flower clusters, number of fruit harvested per tree, and yield for 'Campbell Redchief Delicious' apple trees thinned with four levels of oxamyl and four levels of NAA in 1997 (plots on left side) and 'Mercier Redchief Delicious' trees thinned with two levels of oxamyl and five levels of NAA in 1988 (plots on right side). The response surface was estimated with orthogonal polynomials and $P$-values for significant main effects and interactions are presented in each plot; NS indicates nonsignificance of main effects and interactions.

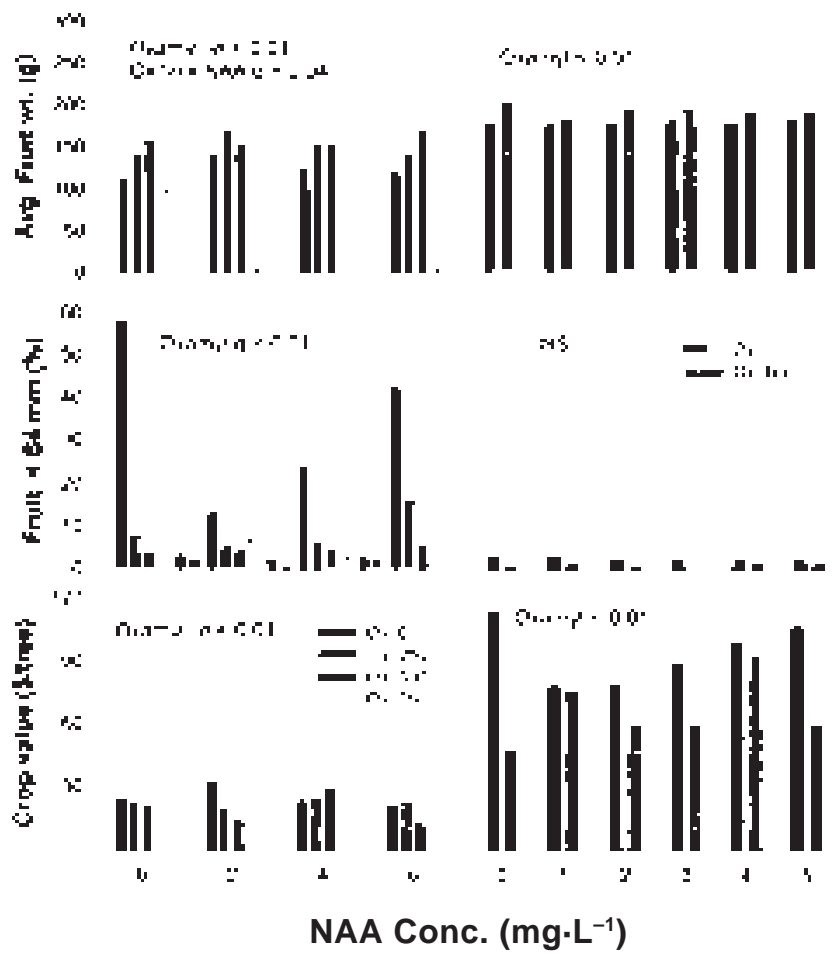

Fig. 2. Average fruit weight, percentage of fruit $<64 \mathrm{~mm}$ in diameter, and crop value for 'Campbell Redchief Delicious' apple trees thinned with four levels of oxamyl and four levels of NAA in 1997 (plots on left side) and 'Mercier Redchief Delicious' trees thinned with two levels of oxamyl and five levels of NAA in 1988 (plots on right side). The response surface was estimated with orthogonal polynomials and $P$-values for significant main effects and interactions are presented in each plot; NS indicates nonsignificance of main effects and interactions. 
centages of small fruit were harvested from trees treated with carbaryl plus high rates of NAA. Both main effects and their interaction influenced crop value. Adding carbaryl to low concentrations of NAA $\left(<8 \mathrm{mg} \cdot \mathrm{L}^{-1}\right)$ increased crop value, but adding carbaryl to higher concentrations or NAA reduced crop value (Fig. 4). In 1999 the main effects of both materials influenced average fruit weight, but the interaction was nonsignificant $(P=0.93)$ (Fig. 4). At all concentrations of NAA, the addition of carbaryl consistently increased average fruit weight, and fruit weight increased linearly with increasing concentration of NAA. The percentage of small fruit was reduced by carbaryl, and declined linearly as the concentration of NAA was increased. The interaction of the two factors was nonsignificant $(P=0.28)$. In 1999 crop value was not significantly influenced by the main effect of either material, but the carbaryl $\times \mathrm{NAA}_{\text {linear }}$ interaction was significant. Crop value was highest for trees treated with NAA at 10.5 and $14 \mathrm{mg} \cdot \mathrm{L}^{-1}$ because those trees had high yields and a low percentage of small fruit. The addition of carbaryl to low concentrations of NAA had little effect on crop value, but the addition of carbaryl to high concentrations of NAA reduced crop value.

\section{Discussion}

Pomologists have been evaluating NAA and carbaryl for thinning apple trees since the 1940 s and 1960s, respectively. Dose-response studies have been published for NAA, but not for NAA when combined with carbamates. The fruit set response varied for different cultivars. For 'Golden Delicious' fruit set usually declined linearly as NAA concentrations increased from 0 to $10 \mathrm{mg} \cdot \mathrm{L}^{-1}$ (Harley et al., 1957; Thompson and Rogers, 1958). For 'Delicious' and 'Rome', fruit set tended to decline at a decreasing rate as NAA concentration was increased (Harley et al., 1957). Results from the current study with 'Smoothee' agree with previous studies where fruit set was linearly and negatively related to NAA concentration. However, results from this study do no agree with previous studies for NAA on 'Delicious'. The primary reason for a discrepancy in results may be that the 'Delicious' trees used in the 1950 s were nonspur cultivars and those used in the present study were spur types. Observations in Virginia orchards indicate that nonspur 'Delicious' strains are more responsive to thinning treatments and adequate thinning is often obtained with NAA. Southwick and Weeks (1957) overthinned 'Delicious' with NAA at $15 \mathrm{mg} \cdot \mathrm{L}^{-1}$. NAA has inconsistently thinned spur 'Delicious' trees. When 'Campbell Redchief Delicious' trees were treated with NAA at $0,2.5$, and $5 \mathrm{mg} \cdot \mathrm{L}^{-1}$ when fruit diameter averaged $4 \mathrm{~mm}$, crop load was linearly and negatively related to NAA concentration. When 'Oregon Spur Delicious' were treated with 0,5 , and $10 \mathrm{mg} \cdot \mathrm{L}^{-1}$, the highest concentration thinned less than the intermediate concentration (Marini, 1996).
Carbaryl is an effective thinner, but results vary little over a concentration range of 440 to $1800 \mathrm{mg} \cdot \mathrm{L}^{-1}$ (Batjer and Thompson, 1961). However, when oxamyl was applied to spur 'Delicious' trees at concentrations of 100 to $1200 \mathrm{mg} \cdot \mathrm{L}^{-1}$, fruit set was linearly and negatively related to oxamyl concentration (Marini, 1997). Results from this study, where oxamyl was applied at 0 to $750 \mathrm{mg} \cdot \mathrm{L}^{-1}$, also indicate that the thinning response depends on concentration, but the response was not linear.

Few experiments have been designed to evaluate the interaction of NAA and carbamates over a range of NAA concentrations. A factorial experiment, where 'Starkrimson Delicious' trees were treated with carbaryl or $\mathrm{NAA}$ at $10 \mathrm{mg} \cdot \mathrm{L}^{-1}$, indicated that NAA was more effective than carbaryl, and the combination overthinned the trees (Byers, 1978). When combinations of carbaryl and NAA were applied to spur strains of 'Delicious', at 4 or $9 \mathrm{~mm}$ fruit diam., NAA at 2.5 or $5 \mathrm{mg} \cdot \mathrm{L}^{-1}$ thinned to a similar level as carbaryl. However, the interaction of the two chemicals was nonsignificant $(P=0.05)$ and the combination of the two chemicals was no more effective than either one alone (Marini, 1996). Byers (1978) found that carbaryl effectively thinned 'Spur Golden Delicious' and the addition of superior oil increased the amount of thinning. In the present study, carbaryl effectively thinned 'Smoothee' trees in 1999, but not in 1997, and the combination of the two

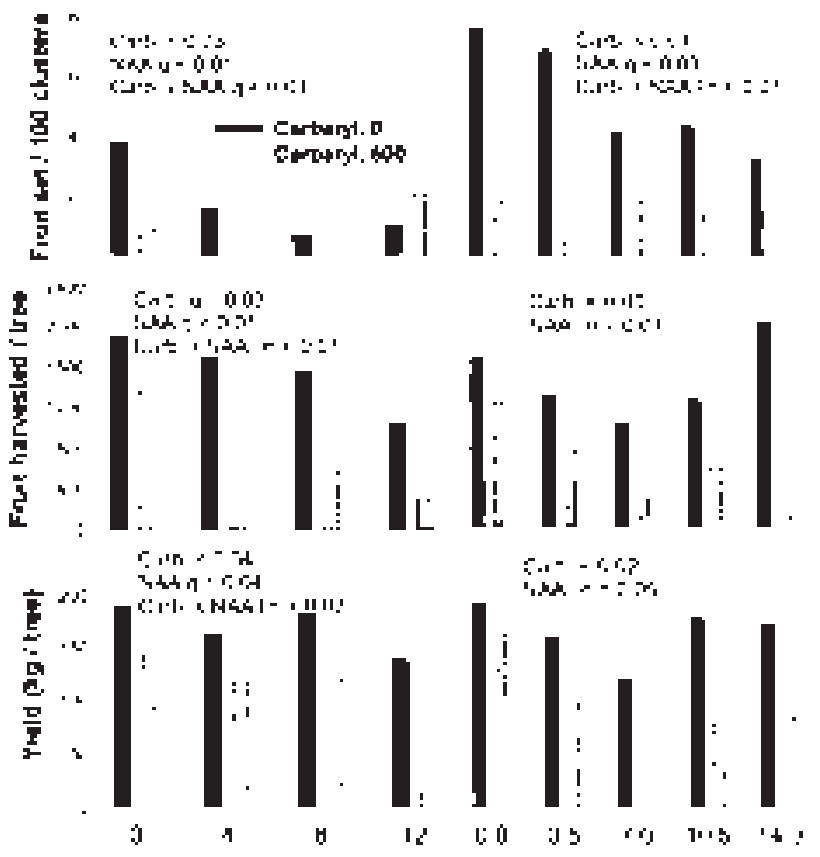

NAA Conc. $\left(\mathrm{mg} \cdot \mathrm{L}^{-1}\right)$

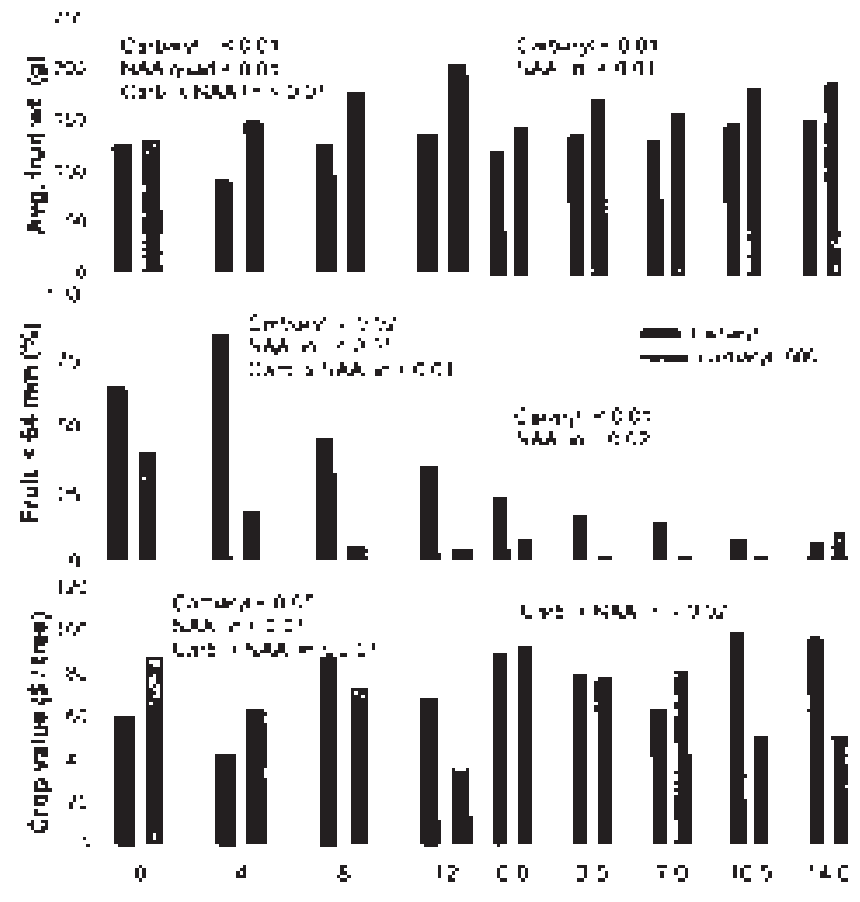

NAA Conc. $\left(\mathrm{mg} \cdot \mathrm{L}^{-1}\right)$

Fig. 4. Average fruit weight, percentage of fruit $<64 \mathrm{~mm}$ in diameter, and crop value for 'Smoothee Golden Delicious' apple trees thinned with two levels of carbaryl and four levels of NAA in 1997 (plots on left side) or thinned with two levels of carbaryl and five levels of NAA in 1999 (plots of right side). The response surface was estimated with orthogonal polynomials and $P$-values for significant main effects and interactions are presented in each plot.
Fig. 3. Fruit set per 100 flower clusters, number of fruit harvested per tree, and yield for 'Smoothee Golden Delicious' apple trees thinned with two levels of carbaryl and four levels of NAA in 1997 (plots on left side) or thinned with two levels of carbaryl and five levels of NAA in 1999 (plots of right side). The response surface was estimated with orthogonal polynomials and $P$-values for significant main effects and interactions are presented in each plot. 

vested per tree both years.

In previous experiments, fruit set on spur 'Delicious' trees declined linearly with increasing concentrations of oxamyl, but this relationship changed when NAA was added (Marini, 1997). At oxamyl concentrations $<400 \mathrm{mg} \cdot \mathrm{L}^{-1}$, the addition of NAA increased thinning. However, when oxamyl was applied at concentrations of $600 \mathrm{or} 800 \mathrm{mg} \cdot \mathrm{L}^{-1}$, thinning was similar with or without the addition of NAA. In the current study, fruit set was reduced to a similar extent by oxamyl at concentrations of 250 to $750 \mathrm{mg} \cdot \mathrm{L}^{-1}$ in 1997 , but in both years combining NAA with oxamyl did not increase the thinning activity of oxamyl.

Although NAA sometimes thinned effectively, fruit size was not always increased (Marini, 1996). To determine if chemical thinners had a direct effect on fruit weight, average fruit weight was plotted against the number of fruit harvested per tree. Analysis of covariance, using number of fruit per tree as the covariate and NAA and oxamyl as the class variables indicated that average fruit weight was negatively and linearly related to the number of fruit harvested per tree, but the thinning treatments did not alter the general relationship (data not presented). Although average fruit weight is often reported for many types of experiments, it may be less important than the chemicals reduced the number of fruit har-

fruit size distribution (Fig. 5). In 1997, average fruit weight increased with increasing oxamyl concentration but, at a given oxamyl concentration, was influenced little by NAA (Fig. 1). Histograms of fruit size distributions show that $\approx 90 \%$ of the crop on control trees were in the two smallest categories (1 and 2) and the percentage was reduced to $76 \%$ with the application of NAA at $6 \mathrm{mg} \cdot \mathrm{L}^{-1}$ (Fig. 5). When trees were treated with oxamyl at $500 \mathrm{mg} \cdot \mathrm{L}^{-1}$, $\approx 15 \%$ of the fruit were in the two smallest categories and $\approx 85 \%$ were in categories 3,4 , and 5 . However, when NAA at $6 \mathrm{mg} \cdot \mathrm{L}^{-1}$ was combined with oxamyl, a similar percentage of fruit fell into the two smallest categories, but nearly $9 \%$ fell into the largest category. In 1998, average fruit weight was slightly increased by oxamyl and was not influenced by NAA (Fig. 2). Although average fruit size was little affected by treatment, the distributions of fruit sizes were influenced by treatment. When applied alone, NAA decreased the percentage of fruit in the three smallest size categories and increased the percentage of fruit in the largest size category (Fig. 5). Oxamyl increased the percentage of fruit in the two largest categories. When combined with oxamyl, NAA slightly increased the percentage of small fruit compared to oxamyl alone. In previous studies, NAA has reduced average fruit size, probably due to the production of pygmy

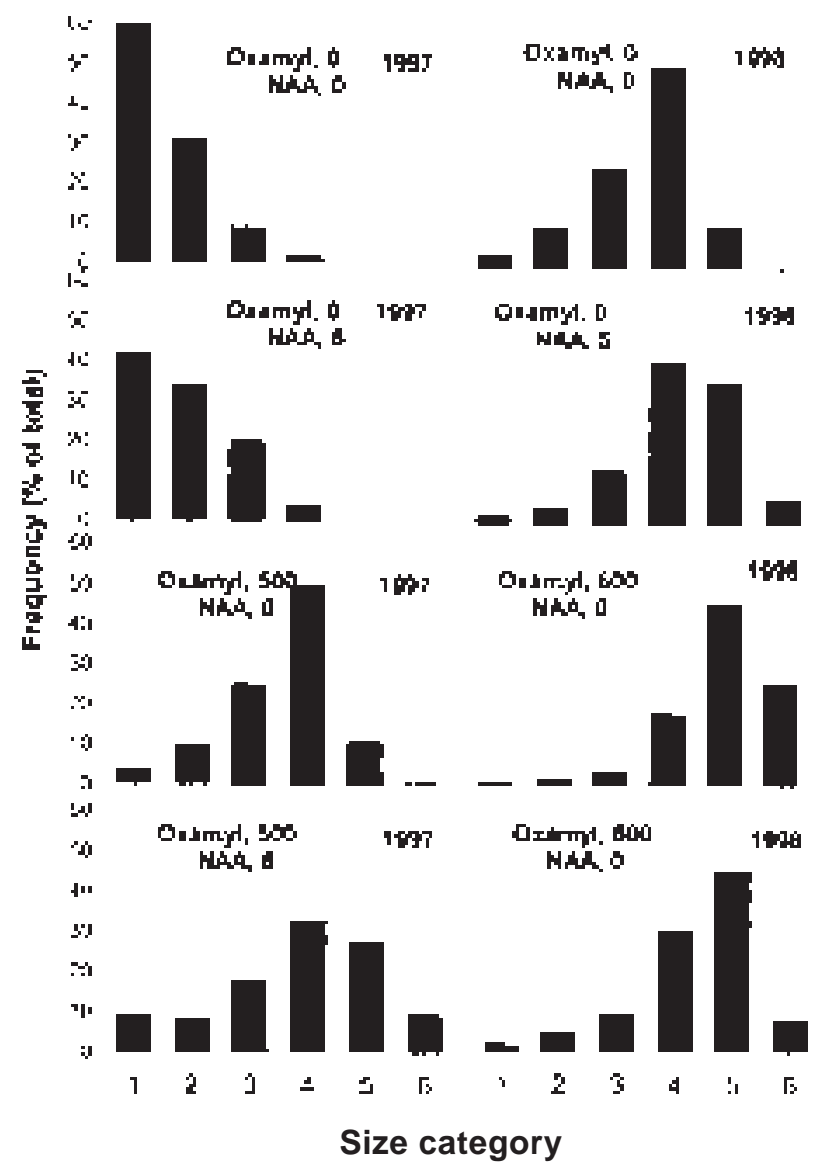

Fig. 5. Fruit size distribution of 'Redchief Delicious' apples harvested from trees thinned with two levels of oxamyl and NAA in 1997 and in 1998. Size categories correspond to the following fruit diameters: $1=<50 \mathrm{~mm}, 2=59 \mathrm{~mm}, 3=65 \mathrm{~mm}, 4=72 \mathrm{~mm}, 5=75 \mathrm{~mm} 6=87 \mathrm{~mm}$, and $7=93 \mathrm{~mm}$. fruit (Byers, 1978). In a four-year study, Rogers and Williams (1977) found that NAA at $7.5 \mathrm{mg} \cdot \mathrm{L}^{-1}$ significantly reduced the crop load two of four years, and the average fruit diameter was increased $>10 \%$ in three of the four years. However, in one of the four years, NAA severely reduced average fruit size due to excessive numbers of pygmy fruits. In the same study, carbaryl was applied three years and reduced the crop load only one year, but increased average fruit diameter by $>12 \%$ every year. In Michigan, NAA applied at the rate of $30 \mathrm{~g} / \mathrm{ha}$, in varying volumes of water per ha, did not reduce yield, but slightly increased the percentage of small fruit in one of two years (Black et al., 1995). In a 2-year study, NAA was applied at the rate of $15 \mathrm{mg} \cdot \mathrm{L}^{-1}$ when average king fruit diameter varied from 4.6 to $20.6 \mathrm{~mm}$. The first year NAA did not affect yield or average fruit weight; in the second year NAA, applied only when average fruit diam. was $12.1 \mathrm{~mm}$, reduced yield and produced a high percentage of small fruit (Black et al., 1995). Pygmy fruit were not observed in the current study, probably because the rates of NAA were relatively low and treatments were applied when average fruit diameter was $8 \mathrm{~mm}$. Pygmy fruit formation was reduced by using low rates of NAA and by making applications soon after bloom (Rogers and Williams, 1975). Personal observations indicated that few pygmy fruits developed when NAA was applied at concentrations $>10 \mathrm{mg} \cdot \mathrm{L}^{-1}$ and when NAA was applied when average fruit diameter was $>10 \mathrm{~mm}$. The inconsistent effect of NAA on the production of small fruit may be related to the number of fruit set per spur. Some years trees thinned with NAA have predominantly one fruit per cluster, but other years there are more than one fruit per cluster. Black et al. (1995) found that NAA reduced fruit weight only when there was more than one fruit per cluster.

Crop value is a function of yield and the distribution of fruit sizes. In this study, as in others (Marini, 1996 \& 1997), treatments that effectively thinned trees also reduced crop value in the year of treatment. Chemical thinners generally do not increase fruit size enough to offset the reduced yields. However, chemical thinning usually encourages return bloom and annual cropping. Net profit may be increased more than crop value the year of treatment. Conversations with commercial packinghouse operators indicate that the labor cost for packing a box of apples greatly increases as packout declines due to poor color, fruit finish, and fruit size. Chemical thinners generally increase the percentage of non-juice apples, and should therefore improve the packout and reduce harvest and packing costs.

Results from this study indicate that when used at rates registered as an insecticide, oxamyl thins spur 'Delicious'. Oxamyl does not thin adequately some years and other treatments need to be evaluated. Adding NAA to a carbamate insecticide, may not improve thinning on spur 'Delicious'. NAA at concentrations of $\approx 6$ to $8 \mathrm{mg} \cdot \mathrm{L}^{-1}$, combined with carbaryl, was needed to adequately thin 'Smoothee' in this study. 


\section{Literature Cited}

Batjer, L.P. and B.J. Thompson. 1961. Effect of 1naphthyl N-Methylcarbamate (Sevin) on thinning apples. Proc. Amer. Soc. Hort. Sci. 77:1-8.

Black, B.L. M.J. Bukovac, and J. Hull, Jr. 1995. Effect of spray volume and time of NAA application on fruit size and cropping of Redcheif 'Delicious' apple. Scientia Hort. 564:253-264.

Byers, R.E. 1978. Chemical thinning of spur 'Golden Delicious' and 'Starkrimson Delicious' with sevin and vydate. HortScience 13:59-61.

Byers, R.E., C.G. Lyons, Jr., and R.L. Horsburgh. 1982. Comparison of sevin and vydate for thinning apples. HortScience 17:777-778.
Harley, C.P., H.H. Moon, and L.O. Regeimbal. 1957. Effects of the additive tween 20 and relatively low temperatures on apple thinning by naphthaleneacetic acid sprays. Proc. Amer. Soc. Hort. Sci. 69:21-27.

Littell, R.C., R.J. Freund, and P.C. Spector. 1991. SAS system for linear models. $3^{\text {rd }}$ ed., SAS Inst., Cary, N.C.

Marini, R.P. 1996. Chemically thinning spur 'Delicious' apples with carbaryl, NAA, and ethephon at various stages of fruit development. HortTechnology 6:241-246.

Marini, R. 1997. Oxamyl is an effective apple fruit thinner when used alone or when combined with other thinners. HortTechnology 7:253-258.
Marini, R.P. 2001. Evaluation of two methods for estimating average fruit weight for apple trees. J. Amer. Soc. Hort. Sci. 125:503-510.

Rogers, B.L. and G.R. Williams. 1977. Chemical thinning of spur-type 'Delicious' apple trees. Virginia Fruit 65:23-28.

Southwick, F.w. and W.D. Weeks. 1957. The influence of naphthaleneacetic acid and naphthaleneacetamide during a four-year period on thinning and subsequent flowering of apples. Proc. Amer. Soc. Hort. Sci. 69:28-40.

Thompson, A.H., and B.L. Rogers. 1958. Some factors affecting chemical thinning of Golden Delicious apples with naphthaleneacetic acid plus tween 20. Proc. Amer. Soc. Hort. Sci. 72:45-51. 